\title{
Characterization and Fertility Status of the Soils of Ayehu Research Substation, Northwestern Highlands of Ethiopia
}

\author{
Getachew Fisseha ${ }^{1}$ and Heluf Gebrekidan ${ }^{2 *}$ \\ ${ }^{1}$ Bahir Dar University, P O Box 79, Bahir Dar, Ethiopia \\ ${ }^{2}$ Haramaya University, P O Box 4, Haramaya University, Ethiopia
}

\begin{abstract}
The pedogenic properties and fertility status of the soils at Ayehu Substation of the Amhara Region Agricultural Research Institute were studied both in the field and through laboratory analysis. On the basis of in situ description of two soil profiles and laboratory analysis, the soils of the study site qualified for the Nitisol soil group as per the FAO/UNESCO Soil Grouping System. The soils were moderately acidic in reaction and silty clay to clay in texture. The pedons exhibited increasing clay contents with depth qualifying for argillic (Bt) horizons. The surface horizons of both pedons revealed the lowest and the bottom (Bt3) horizons indicate the highest bulk density values. The consistent increase of bulk density with depth is apparently due to the decreasing level of organic carbon (OC) with depth from 2.6 to $0.6 \%$ in pedon 1 and from 2.8 to $1.1 \%$ in pedon 2 . The lowest total porosity $(44.2 \%)$ was observed in the $\mathrm{Bt} 3$ horizon of pedon 1 and the highest $(55.2 \%)$ in the composite surface soil collected around pedon 2 . Throughout the depths of the two pedons and surface soil samples, $\mathrm{pH}\left(\mathrm{H}_{2} \mathrm{O}\right)$ values were higher than $\mathrm{pH}(\mathrm{KCl})$ resulting in positive $\Delta \mathrm{pH}$ values and indicating the presence of variable charge clay surfaces. The subsoil horizons showed lower values of cation exchange capacity (CEC) and percentage base saturation suggesting intensive weathering and presence of 1:1 (kaolinitic) clay minerals. The quantity of exchangeable $\mathrm{Na}$ was trace whilst appreciable amount of exchangeable $\mathrm{K}$ was available in both pedons. The surface horizons contained high exchangeable $\mathrm{Ca}$ and $\mathrm{Mg}$ to the extent that the sum of these bases occupied over $83 \%$ of the CEC in both pedons. In accordance with OC, total $\mathrm{N}$ decreased with depth from 0.19 to $0.05 \%$ in pedon 1 and from 0.22 to $0.10 \%$ in pedon 2 . The highest contents of Olsen $\mathrm{P}\left(3.21 \mathrm{mg} \mathrm{l}^{-1}\right)$ and Bray P (4.40 $\mathrm{mg} \mathrm{l}^{-1}$ ) were obtained in the surface horizon of pedon 1 and both showed decreasing trends with depth in the two pedons. Application of increasing rates of $\mathrm{P}$ fertilizer increased both the Olsen and Bray II P consistently, while applied rates of $\mathrm{N}$ did not bring significant change in soil total $\mathrm{N}$ content.
\end{abstract}

Keywords: Ayehu Area; Bray II Available P; Nitisols; Olsen Available P; Pedon

\section{Introduction}

Soil and water resources and the methods of their exploitation on sustainable basis dictate food production and ultimately human survival. The regions of highest food production have been those with favorable climate, relatively fertile soils, and an adequate supply of water. The success of soil management to maintain soil quality depends on understanding the soil characteristics and the responses of soils to agricultural use and management practices over time (Wakene and Heluf, 2003; Mohammed et al., 2005). Land use and management influence most of the agriculturally relevant soil morphological, physical, chemical and biological characteristics (Martel and Mackenzie, 1980; Kang, 1993; Saikh et al., 1998a, 1998b; Wakene and Heluf, 2003).

The soils of the Ethiopian highlands are highly variable, varying greatly in their inherent natural characteristics and productive capacities. This is attributed to the extremely rugged terrain, widely varying topography and mountainous landscape which further govern the variations in regional geomorphologies, soil parent materials, soil toposequences, agroecological zones (climate), land use and types of plant and animal lives in a given area. As a result, many soil types differing from each other in their morphological, physical, chemical, mineralogical, and biological properties occur on a given landscape along a toposequence (Mishra et al., 2004; Mohammed et al., 2005). The fertility, water holding capacity, susceptibility to erosion and potential productivity of these soil types differ from each other significantly. Therefore, soil characterization and classification which provide with knowledge on soil properties are vital in designing appropriate management strategies in agriculture and natural resources for sustainable development.

Soil fertility declines when its nutrient content diminishes, and its quality to meet plant requirements is lowered. Soil nutrient depletion in smallholding farming systems is recognized as a causal force leading to food insecurity and rural poverty in Africa (Smaling et al., 1997; FAO, 2001). Declining soil fertility has also been stressed to be the fundamental impediment to agricultural development and the major reason for the slow growth in food production in Ethiopia (Asfaw et al., 1997). As a result, greater emphasis has been given to examination of nutrient cycles and budgets at scales ranging from farm to regional levels. However, successful examinations of nutrient cycles and budgets necessitate data of inherent soil physicochemical properties and fertility status as the existing soil quality (stock) is the basis for such examination. Generally, the 
available scientific information on soil characteristics and fertility depletion and its consequences on agricultural productivity and the livelihoods of smallscale farming communities in sub-Saharan countries has contributed to the development and implementation of strategies for soil fertility replenishment in developing countries.

The first criterion in making a valid fertilizer recommendation is to know the soil test level of the specific nutrient in the soil. Successful soil test method should be able to predict whether or not a response is expected as well as the magnitude of that response. Since environmental conditions, soils and crops vary from place to place, it is necessary to select a suitable soil test method for each local condition. However, in Ethiopia, a few indicative $\mathrm{P}$ calibration studies have been carried out. Tekalign and Haque (1991) reported that the Olsen method estimated plant available $\mathrm{P}$ reliably on contrasting soil types indicating that the method is of more general application on wider range of soils than in calcareous soils for which it was first recommended.

Thus, understanding the physicochemical characteristics and the fertility status of a given soil play a vital role in designing appropriate management strategies for enhancing productivity of the agricultural sector and sustainable utilization of natural resources. Hence, in order to generate such information at and around the Ayehu Research Substation in the northwestern Ethiopia, this study was undertaken to characterize the soils of the study area on the basis of some selected physicochemical properties and reveal their fertility status.

\section{Materials and Methods}

\subsection{Description of the Study Area}

The study was conducted at the experimental and seed multiplication site of the Ayehu Research Substation of Adet Agricultural Research Center in the Amhara National Regional State, Ethiopia. The Ayehu Research Substation is located in Ankasha District (Fig. 1) at about 435 and $30 \mathrm{~km}$ distances, in the north direction (Finote Selam-Bahir Dar Road), from Addis Ababa city and Kesa town, respectively. It is situated at $11^{\circ} 20^{\prime} \mathrm{N}$ latitude and $37^{\circ} 25^{\prime} \mathrm{E}$ longitude and an altitude of 1900 $\mathrm{m}$ above sea level (masl). The rainy season covers from April to November and maximum rain is received in the months of June, July, August and September. According to the weather data recorded at the Ayehu meteorological station, the average annual rainfall is $1100 \mathrm{~mm}$, and the mean maximum and mean minimum temperatures are 30.6 and $13.6{ }^{\circ} \mathrm{C}$, respectively (data taken from Ayehu meteorological station). The area is characterized by a subhumid tropical climate and falls under the tepid to cool moist mid highlands (M2) agroecological zone.

The study area lies on an upland landform that is predominantly characterized by almost flat to gently undulating topography. A larger proportion of the study area and the surroundings fall in the slope ranges of nearly level $(0.5-1.0 \%)$ to gently slopping (2.0-5.0\%) with a slope aspect of northwest direction. Basalt is the dominant parent material from which the soils at and around the study area have been formed through in situ weathering. The soils at the study area are generally highly weathered, very deep and moderately well to well drained. Intensive rainfed cultivation of annual field crops mainly cereal crops constitute the land use in the area. The dominant crops grown in the area are maize (Zea mays), wheat (Triticum spp.), teff (Eragrostis tef) and hot pepper (Capsicum frutescence).

A field experiment involving fertilization of wheat crop with factorial combinations of five levels of $\mathrm{N}(0$, 23, 46, 69 and $\left.92 \mathrm{~kg} \mathrm{~N} \mathrm{ha}^{-1}\right)$ and five levels of $\mathrm{P}(0,10$, 20, 30 and $40 \mathrm{~kg} \mathrm{P} \mathrm{ha}^{-1}$ ) fertilizers was also conducted on the site where Pedon 1 was characterized during the time of profile study. The objectives of the study were to determine the effects of $\mathrm{N}$ and $\mathrm{P}$ fertilizers on yield, yield components and nutrient uptake of wheat and to reveal the residual effects of these fertilizers on soil $\mathrm{N}$ and available $\mathrm{P}$ contents. The full dose of $\mathrm{P}$ fertilizer was applied as triple super phosphate $(20 \%$ P) at planting, while $\mathrm{N}$ was split applied (half of the dose at planting and half at 30 days after planting) as Urea: $46 \% \mathrm{~N})$.

\subsection{Soil Sampling}

Two representative soil profile pits of $2 \mathrm{~m}$ width $\mathrm{x} 2 \mathrm{~m}$ length and $2 \mathrm{~m}$ depth were excavated based on site survey and preliminary inspection of the auger-sampled soil samples. The soil profiles were described for their morphological properties according to the FAO guidelines (FAO, 1990) and samples were taken from all identified horizons for characterization of selected physical and chemical properties (particle size distribution, bulk density, particle density, porosity, $\mathrm{pH}$, organic matter, total $\mathrm{N}$, available $\mathrm{P}, \mathrm{CEC}$ and exchangeable cations) through laboratory analysis. In addition to the soil profile samples, six composite surface soil samples $(0-30 \mathrm{~cm}$ depth) were collected from representative spots of the entire experimental plot and the fields nearby the two pedons for laboratory analysis of the above indicated soil physicochemical properties before planting. Similarly, surface soil samples at the same depth were collected from each plot after crop harvest and finally bulked by replication to obtain one representative composite sample per treatment for determination of soil $\mathrm{P}$ and $\mathrm{N}$ contents. Undisturbed duplicate soil samples were taken using core sampler from the surface layer of the experimental field and from every horizon of the two pedons for the determination of bulk density.

\subsection{Analysis of Soil Physical and Chemical Properties}

The surface and profile soil samples collected from the study area were air dried and crushed to pass through 2 $\mathrm{mm}$ sieve for the analysis of $\mathrm{pH}$, particle size distribution, CEC, exchangeable cations, available $\mathrm{P}$, organic matter and total nitrogen. Soil color (dry and moist) was determined using the Munsell soil color chart in the field. Particle size distribution was analyzed by the modified Bouyoucos hydrometer method (Bouyoucos, 1962). Bulk density was estimated from 
Amhara Region Administrative Districts

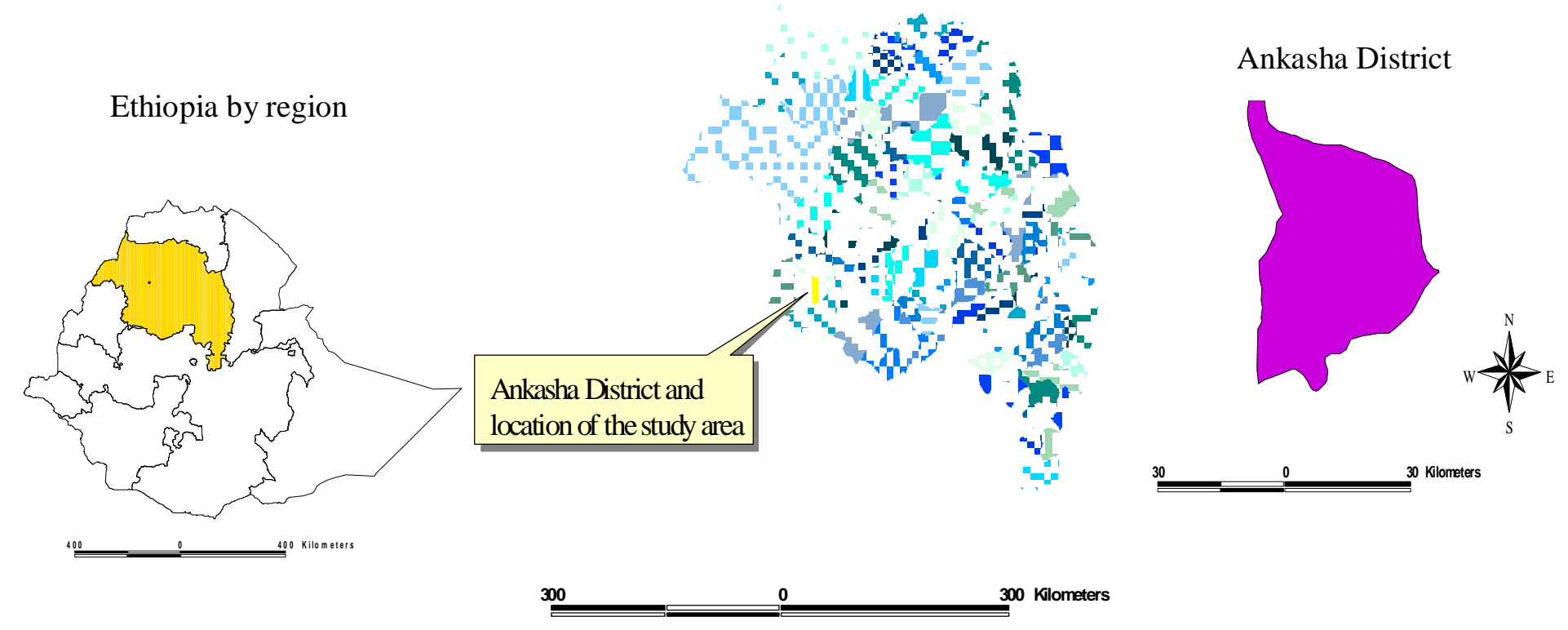

Figure 1. Location map of the Ayehu Research Substation within the Ankasha District 
undisturbed soil samples collected using core sampler from every identified genetic horizon and surface layers. Particle density was determined by the pycnometer method (Blake, 1965) and finally calculated as the mass of the solid particles per unit volume of the soil solids. Total porosity was estimated from the values of bulk density $(\mathrm{Db})$ and particle density (Dp) as:

$$
\text { Total porosity }(\%)=\left(1-\frac{D b}{D p}\right) \times 100
$$

The $\mathrm{pH}$ of the soil was measured potentiometrically using a $\mathrm{pH}$ meter in the supernatant suspension of 1:2.5 soil to liquid ratio of water and $1 \mathrm{M} \mathrm{KCl}$ solution and $\Delta \mathrm{pH}$ was determined by subtracting soil $\mathrm{pH}(\mathrm{KCl})$ from soil $\mathrm{pH}\left(\mathrm{H}_{2} \mathrm{O}\right)$. Cation exchange capacity (CEC) of the soil was determined by the ammonium acetate ( $\mathrm{pH} 7.0)$ method whereby ammonium ion was replaced by $\mathrm{Na}$ from percolating sodium chloride solution (Chapman, 1965) and reported as CEC. Exchangeable bases were extracted with $1 \mathrm{M}$ ammonium acetate at $\mathrm{pH}$ 7.0. Exchangeable $\mathrm{Ca}$ and $\mathrm{Mg}$ were measured from the extract with atomic absorption spectrophotometer while exchangeable $\mathrm{K}$ and $\mathrm{Na}$ were determined from the same extract with flame photometer. Percent base saturation was determined as the percentage of total exchangeable bases to the CEC of the soil. Organic carbon content was determined following the wet digestion method as described by Walkley and Black (1934), whereas the Kjeldahl procedure was followed for the determination of total nitrogen as described by Jackson (1970). Available $\mathrm{P}$ was determined using both the Olsen (Olsen et al., 1954) and Bray II (Bray and Kurtz, 1945) extraction methods. The absorbance of available $\mathrm{P}$ extracted by both methods was measured using spectrophotometer after color development.

\section{Results and Discussion}

\subsection{Soil Site and Morphological Features}

There was not much difference in the characteristics of the sites on which the two pedons were excavated. Accordingly, the majority of the areas represented by both of the pedons studied were cultivated for maize, wheat, triticale and other field crops. The site where pedon 1 was located is very gently sloping (1.0-2.0\% slope) with slight to moderate sheet erosion. On the other hand, the site of pedon 2 is gently sloping (2.0$5.0 \%$ slope) affected by moderate sheet and slight rill erosion. Similarly, the soils on both sites were developed from basalt parent material and both were very deep (> $200 \mathrm{~cm}$ ) and moderately well to well drained.

The surface layers $(0-25$ and $0-20 \mathrm{~cm})$ of the soils represented by pedons 1 and 2 , respectively, were dark reddish brown (5YR 3/3 and 5YR 5/4) in color when dry and dark brown (7.5YR $3 / 2$ and 5YR 3/4) when moist (Table 1). In the subsurface horizons, there was no variation in dry soil color (5YR $3 / 4$ to $5 \mathrm{YR} 4 / 6$ ) in pedon 1 while it varied from $5 \mathrm{YR} 5 / 4$ to $2.5 \mathrm{YR} 4 / 6$ in pedon 2. Similarly, the moist soil color of the subsoil layers varied from 5YR 3/4 (Bt1) to 2.5YR 4/6 (Bt3) in pedon 1 and from 5YR 3/4 (Bt1) to $2.5 \mathrm{YR} 4 / 3(\mathrm{Bt} 3)$ in pedon 2. The soil structure was weak, fine granular at the surface and weak, fine and medium subangular blocky in the Bt1 horizons of both pedons (Table 1). In the $\mathrm{Bt} 2$ horizons, the structure of pedon 1 changed to moderate, medium subangular blocky while that of the Bt3 of both pedons had moderate, fine angular blocky structure. The roots observed in the surface horizon of pedon 1 were common, fine and medium while that of pedon 2 were many, medium and coarse which decreased progressively with depth to none in the Bt3 horizons of both pedons.

The soils represented by both profiles were very deep as the total depth of both profiles was greater than 200 $\mathrm{cm}$. The thicknesses of the Ap horizons were $25 \mathrm{~cm}$ in pedon 1 and $20 \mathrm{~cm}$ in pedon 2 . The subsoil horizons showed a progressive increase in thickness with profile depth in both pedons. Accordingly, the boundary of the surface horizons which was described to be abrupt and smooth in both pedons changed to gradual and smooth in pedon 1 and to gradual to clear and smooth in pedon 2 in their subsoil horizons (Table 1).

The soil consistence of the top soils were soft (dry), very friable (moist) and slightly sticky and slightly plastic (wet) in pedon 1 and soft (dry), friable (moist) and sticky and plastic (wet) in pedon 2. These changed to slightly hard to hard and very hard (dry), friable to firm (moist) and sticky and plastic (wet) in the subsoil layers of both profiles (Table 1). The shiny faces observed in the ped faces of the $\mathrm{Bt} 2$ and $\mathrm{Bt} 3$ horizons of both pedons exhibited the presence of nitic properties which is considered as one of the major diagnostic characteristics of the Nitisols major soil group (FAO, 1998).

\subsection{Soil Physical Properties}

The surface layers $(0-25$ and $0-20 \mathrm{~cm})$ of pedons 1 and 2 , respectively, and the surface soils represented by both soil profiles were silty clay in texture. However, the subsoil horizons of both pedons were clayey in texture (Table 2). Both pedons exhibited high levels of clay accumulation in the subsoil horizons. There was no marked difference in particle density between the two pedons and the surface soil samples. The highest soil particle density $\left(2.51 \mathrm{~g} \mathrm{~cm}^{-3}\right)$ was noted at the Bt3 horizons of the two pedons, whilst the lowest $(2.45 \mathrm{~g}$ $\mathrm{cm}^{-3}$ ) was recorded at the surface horizon of pedon 2 (Table 2). The lowest bulk density values were recorded at the surface horizons.

The results obtained from this study are in agreement with Brady and Weil (2002) who indicated that the bulk density increased with increasing soil depth and the highest bulk density occurred at the C-horizon. Wakene and Heluf (2003) also reported highest bulk density values at the bottom layers of the Cambisol and Nitisol profiles under the farmer's field and on the virgin land, respectively, in Bako area of Ethiopia. However, the same authors reported the highest bulk density value in the surface layer of the Alisol profile of the area that was under intensively cultivated research field for over three decades. The increasing bulk density with soil profile depth in the present study is apparently due to the lower content of organic matter, which was $0.61 \%$ in the $\mathrm{Bt} 3$ as compared to $2.60-2.80 \%$ in the surface horizon (Table 3). Besides to the low organic matter, less aggregation and root penetration and compaction 
Table 1. Morphological features and classification of Ayehu area soils

\begin{tabular}{|c|c|c|c|c|c|c|c|c|c|}
\hline \multirow{2}{*}{$\begin{array}{c}\text { Depth } \\
\text { (cm) }\end{array}$} & \multirow[t]{2}{*}{ Horizon } & \multirow{2}{*}{$\begin{array}{l}\text { Boun- } \\
\text { dary* }\end{array}$} & \multicolumn{2}{|c|}{ Color } & \multirow[t]{2}{*}{ Structure } & \multicolumn{3}{|c|}{ Consistence* } & \multirow[t]{2}{*}{ Root } \\
\hline & & & Dry & Moist & & dry & moist & wet & \\
\hline \multicolumn{10}{|c|}{ Pedon 1: Nitisols } \\
\hline $0-25$ & Ap & as & $5 Y R 3 / 3$ & 7.5YR 3/2 & Weak, fine granular & $\mathrm{s}$ & vfr & sssp & Common, fine \& medium \\
\hline $25-50$ & Bt1 & gs & $5 Y R 3 / 4$ & $5 Y R 3 / 4$ & Weak, fine and medium subangular blocky & $\mathrm{h}$ & fr & sp & Few, fine \\
\hline $50-100$ & $\mathrm{Bt} 2$ & gs & $5 \mathrm{YR} 4 / 6$ & $5 \mathrm{YR} 4 / 3$ & Moderate, medium subangular blocky & $\mathrm{h}$ & fi & $\mathrm{sp}$ & Very few, very fine \\
\hline $100-200^{+}$ & Bt3 & - & $5 \mathrm{YR} 4 / 3$ & $2.5 \mathrm{YR} 4 / 6$ & Moderate, Fine angular blocky & vh & fi & $\mathrm{sp}$ & None \\
\hline \multicolumn{10}{|c|}{ Pedon 2: Nitisols } \\
\hline $0-20$ & Ap & as & 5YR 5/4 & 5YR 3/4 & Weak, fine granular & $\mathrm{s}$ & fr & $\mathrm{sp}$ & Many, medium \& coarse \\
\hline $20-50$ & Bt1 & gs & 5YR 5/4 & $5 Y R 3 / 4$ & Weak, fine and medium subangular blocky & sh & fr & $\mathrm{sp}$ & Few, fine and medium \\
\hline $50-130$ & $\mathrm{Bt} 2$ & cs & $2.5 \mathrm{YR} 4 / 6$ & $2.5 Y R 3 / 6$ & Weak, fine \& medium subangular blocky & $\mathrm{h}$ & fi & $\mathrm{sp}$ & Few, very fine \\
\hline $130-200^{+}$ & Bt3 & - & $2.5 \mathrm{YR} 4 / 6$ & $2.5 \mathrm{YR} 4 / 3$ & Moderate, fine angular blocky & $\mathrm{h}$ & fi & sp & None \\
\hline
\end{tabular}

*as = Abrupt and smooth; $g s=$ Gradual and smooth; $c s=$ Clear and smooth; $s=$ Soft; $h=$ Hard; vh = Very hard; sh = Slightly hard; vfr = Very friable; fr = Friable; fi = firm; sp = Sticky and plastic; sssp = Slightly sticky and slightly plastic

Table 2. Soil physical properties

\begin{tabular}{|c|c|c|c|c|c|c|c|c|}
\hline \multirow[t]{2}{*}{ Depth $(\mathrm{cm})$} & \multirow[t]{2}{*}{ Horizon } & \multicolumn{3}{|c|}{ Particle size distribution $(\%)$} & \multirow[t]{2}{*}{ Textural class } & \multirow{2}{*}{$\begin{array}{l}\text { Particle density } \\
\qquad\left(\mathrm{g} \mathrm{cm}^{-3}\right)\end{array}$} & \multirow{2}{*}{$\begin{array}{l}\text { Bulk density } \\
\quad\left(\mathrm{g} \mathrm{cm}^{-3}\right)\end{array}$} & \multirow[t]{2}{*}{ Porosity (\%) } \\
\hline & & Sand & Silt & Clay & & & & \\
\hline \multicolumn{9}{|c|}{ Pedon 1: Nitisols } \\
\hline $0-25$ & Ap & 3.0 & 57.0 & 40.0 & Silty clay & 2.48 & 1.23 & 50.4 \\
\hline $25-50$ & Bt1 & 4.0 & 24.0 & 72.0 & Clay & 2.50 & 1.30 & 48.0 \\
\hline $50-100$ & $\mathrm{Bt} 2$ & 4.0 & 20.0 & 76.0 & Clay & 2.50 & 1.30 & 48.0 \\
\hline $100-200+$ & $\mathrm{Bt} 3$ & 3.0 & 19.0 & 78.0 & Clay & 2.51 & 1.40 & 44.2 \\
\hline \multicolumn{9}{|c|}{ Pedon 2: Nitisols } \\
\hline $0-20$ & Ap & 2.0 & 54.0 & 44.0 & Silty clay & 2.45 & 1.21 & 50.6 \\
\hline $20-50$ & Bt1 & 2.0 & 30.0 & 68.0 & Clay & 2.50 & 1.37 & 45.2 \\
\hline $50-130$ & $\mathrm{Bt} 2$ & 3.0 & 20.0 & 77.0 & Clay & 2.51 & 1.33 & 47.0 \\
\hline $130-200+$ & $\mathrm{Bt} 3$ & 2.0 & 22.0 & 76.0 & Clay & 2.51 & 1.38 & 45.0 \\
\hline \multicolumn{9}{|c|}{ Surface soil samples nearby Pedon 1 including the experimental plot } \\
\hline $0-30$ & - & 4.0 & 46.0 & 50.0 & Silty clay & 2.50 & 1.12 & 55.2 \\
\hline $0-30$ & - & 3.0 & 47.0 & 50.0 & Silty clay & 2.49 & 1.23 & 50.6 \\
\hline $0-30$ & - & 4.0 & 48.0 & 48.0 & Silty clay & 2.50 & 1.19 & 52.4 \\
\hline Mean & - & 3.7 & 47.0 & 49.3 & Silty clay & 2.50 & 1.18 & 52.7 \\
\hline \multicolumn{9}{|c|}{ Composite surface soil samples nearby Pedon 2} \\
\hline $0-30$ & - & 2.0 & 45.0 & 53.0 & Silty clay & 2.50 & 1.17 & 53.2 \\
\hline $0-30$ & - & 3.0 & 43.0 & 54.0 & Silty clay & 2.50 & 1.14 & 54.4 \\
\hline $0-30$ & - & 4.0 & 44.0 & 52.0 & Silty clay & 2.50 & 1.13 & 54.8 \\
\hline Mean & - & 3.0 & 44.0 & 53.0 & Silty clay & 2.50 & 1.15 & 54.1 \\
\hline
\end{tabular}


caused by the weight of the overlying layers have contributed to the increasing bulk density with depth (Brady and Weil, 2002). In contrast to bulk density, the lowest total porosity (44.2\%) was observed at the Bt3 horizon of pedon 1 followed by $45.0 \%$ at the $\mathrm{Bt} 3$ horizon of pedon 2 and the highest (55.2\%) was recorded on the composite surface soil sample collected around pedon 1 (Table 2). This low total porosity was also the reflection of low organic matter content in the subsurface horizons and due to compaction caused by the weight of the soil in the overlying horizons.

\subsection{Soil Chemical Properties}

Throughout the horizons of the two pedons and in the composite surface soil samples, $\mathrm{pH}\left(\mathrm{H}_{2} \mathrm{O}\right)$ was higher than $\mathrm{pH}(\mathrm{KCl})$ (Table 3$)$. Consequently, $\Delta \mathrm{pH}$ values remained positive, which is an indication of variable charge clay surfaces. Sahlemedhin (1999) also reported results in which the values of $\mathrm{pH}\left(\mathrm{H}_{2} \mathrm{O}\right)$ were higher than $\mathrm{pH}(\mathrm{KCl})$ in soils dominated with layer silicate minerals, whereas in the soils dominated by amorphous mineral and oxides of iron and aluminum, the proportion of $\mathrm{pH}$ dependent charges was very high and the $\mathrm{pH}(\mathrm{KCl})$ values were higher than that of $\mathrm{pH}\left(\mathrm{H}_{2} \mathrm{O}\right)$. Considering the $\mathrm{pH}(\mathrm{KCl})$ values, all of the horizons except the $\mathrm{Bt} 3$ ( $\mathrm{pH} 5.1$ ) of profile 1 were strongly acidic $(\mathrm{pH}<5.0)$ throughout the depths of the pedons and the composite surface soils. The soil $\mathrm{pH}\left(\mathrm{H}_{2} \mathrm{O}\right)$ values of both soil pedons and the composite surface soil were in the range of 5-6, which is considered as moderately acidic reaction class (Brady and Weil, 2002).

The organic carbon (Table 3) contents were in the range of 2.4 to $2.9 \%$ across the surface layers of the pedons and the composite surface soils around the pedons. In both pedons, organic carbon was the highest in the surface soils and decreased rapidly and consistently with profile depths. The organic carbon contents of both pedons and the surface soils fall under moderate based on the ratings of soil test values established by Tekalign et al. (1991). The distribution of the total soil $\mathrm{N}$ contents among the pedons and the surface soils $(0.19-0.22 \%)$ is almost similar to the organic carbon and are also considered as moderate as per the ratings of same. The $\mathrm{C}$ : $\mathrm{N}$ ratios of the surface soil layers of both pedons and the average values of the composite surface soil samples varied from 12.2 to 13.7 (Table 3) and these were within the normal ranges for average mineral soils. The relatively higher values of $\mathrm{C}$ : $\mathrm{N}$ ratios in some of the subsoil layers suggest low rate of organic matter decomposition and indicate lower rate of mineralization of organic N.

The CEC and total exchangeable bases decreased consistently from the surface to the subsurface horizons except for the Bt3 horizon of pedon 2 (Table 3). The decrease in CEC with depth could be due to the strong association between organic carbon and CEC, as organic matter content also decreased with depth in both pedons. The subsoil horizons showed relatively lower values of CEC and percentage base saturation values lower than $50 \%$ suggesting high intensity of weathering and the presence of 1:1 (kaolinitic) type minerals. Exchangeable $\mathrm{Na}$ contents of the soils under the two profiles and the surface soil samples were trace. Exchangeable $\mathrm{K}$ decreased almost consistently from the surface to the subsurface horizons on pedon 1, whereas an appreciable amount of $\mathrm{K}$ was recorded in both profiles which made the result in agreement with the common observation that Ethiopian soils are rich in $\mathrm{K}$. Moreover, based on the ratings of Tekalign et al. (1991), which sets that soils consisting of exchangeable $\mathrm{K}$ values greater than $0.77 \mathrm{cmol}(+) \mathrm{kg}^{-1}$ as high in $\mathrm{K}$, the soils of the study area were high to very high in exchangeable $\mathrm{K}$.

In both pedons, the highest values of exchangeable $\mathrm{Ca}$ were recorded in the surface horizons (Table 3). Similarly, exchangeable $\mathrm{Mg}$ was highest in the surface layers of the pedons, and hence exchangeable $\mathrm{Ca}$ and $\mathrm{Mg}$ occupied $84 \%$ and $90 \%$ of the CEC in pedon 1 and pedon 2, respectively. The distribution of exchangeable $\mathrm{Ca}$ and $\mathrm{Mg}$ showed inconsistency with depth in both pedons. Relatively lower $\mathrm{Ca}$ and $\mathrm{Mg}$ concentrations were recorded on the composite surface soil samples analyzed compared to that of the surface layers of the pedons. Considering the results of the composite surface soil samples, soil exchangeable $\mathrm{Ca}$ is in the range of medium $\left(5-8 \mathrm{cmol}(+) \mathrm{kg}^{-1}\right)$ and $\mathrm{Mg}$ is rated as high $\left(0.67-1.50 \mathrm{cmol}(+) \mathrm{kg}^{-1}\right)$ as per the rating suggested by Tekalign et al. (1991).

The percent base saturation values throughout the two pedons and composite surface soil samples were less than $50 \%$. This could be due to the high rainfall and intensive cultivation in the study area that enhanced loss of basic cations through leaching and crop harvest (Singh et al., 1995; Saikh et al., 1998b). Higher organic carbon concentrations were recorded in the surface horizons as compared to the lower depths of the soil profiles. Similarly, the amount of total nitrogen decreased consistently with depth throughout the two pedons (Table 3 ). Considering the surface soil layers, the highest organic carbon $(2.8 \%)$ and total nitrogen $(0.22 \%)$ were obtained in Pedon 2 (Table 3 ).

\subsection{Soil Classification}

The morphological, physical, and chemical properties of pedons 1 and 2 suggest that the soils under both soil profiles qualify the FAO (1998) criteria for classification as Nitisols. According to the FAO (1998), Nitisols are reddish brown soils with nitic properties on the exposed surfaces and exhibit shiny, lustrous ped faces. In both pedons, the soil structure of the Bt horizons ranged from moderate, medium subangular blocky to moderate, fine angular blocky structure. The horizon boundaries were abrupt and smooth in the surface horizons. These changed to gradual and smooth in Pedon 1 and to gradual to clear and smooth in Pedon 2 in their subsoil horizons. The contents of clay throughout the pedons were greater than $30 \%$ and increased considerably with increasing depth from 40 to $78 \%$ in Pedon 1 and from 44 to $77 \%$ in Pedon 2 indicating translocation of clay from the surface soil and its accumulation in the subsoil layers. The Munsell moist color values and chromas were also 5 and 4 or less, respectively. The diagnostic properties and the physicochemical properties suggested the classification of these soils into Nitisols group (FAO, 1998). The shiny ped faces (pressure faces) observed in the $\mathrm{Bt} 2$ and Bt3 horizons of both pedons clearly indicate the existence of Nitic properties which is a major diagnostic property for their classification as Nitisols at a reference 
Table 3. Chemical properties of soils in Ayehu area

\begin{tabular}{|c|c|c|c|c|c|c|c|c|c|c|c|c|c|c|c|}
\hline \multirow{2}{*}{$\begin{array}{l}\text { Depth } \\
\text { (cm) }\end{array}$} & \multicolumn{2}{|c|}{$\mathrm{pH}(1: 2.5)$} & \multirow[t]{2}{*}{$\Delta \mathrm{pH}$} & \multicolumn{2}{|c|}{$\operatorname{AvP}\left(\mathrm{mg} \mathrm{l}^{-1}\right)^{*}$} & \multirow{2}{*}{$\begin{array}{l}\mathrm{TN} \\
(\%)\end{array}$} & \multirow{2}{*}{$\begin{array}{l}\text { OC } \\
(\%)\end{array}$} & \multirow{2}{*}{$\begin{array}{l}\mathrm{C}: \mathrm{N} \\
\text { ratio }\end{array}$} & \multicolumn{6}{|c|}{ CEC and exchangeable bases $\left(\mathrm{cmol}(+) \mathrm{kg}^{-1}\right)$} & \multirow{2}{*}{$\begin{array}{l}\text { PBS } \\
(\%)\end{array}$} \\
\hline & $\mathrm{H}_{2} \mathrm{O}$ & $\mathrm{KCl}$ & & Olsen & Bray & & & & $\mathrm{CEC}$ & $\mathrm{Na}$ & $\mathrm{K}$ & $\mathrm{Ca}$ & $\mathrm{Mg}$ & TEB & \\
\hline \multicolumn{16}{|c|}{ Pedon 1: Nitisols } \\
\hline $0-25$ & 5.88 & 4.77 & 1.11 & 3.21 & 4.40 & 0.19 & 2.6 & 13.70 & 33.5 & trace & 2.66 & 10.36 & 3.55 & 16.57 & 49.46 \\
\hline $25-50$ & 5.56 & 4.29 & 1.27 & 1.80 & 3.80 & 0.10 & 1.5 & 15.00 & 29.5 & trace & 1.90 & 6.22 & 2.42 & 10.54 & 37.33 \\
\hline $50-100$ & 5.70 & 4.52 & 1.18 & 2.13 & 3.80 & 0.07 & 1.0 & 14.30 & 27.9 & trace & 0.72 & 7.73 & 2.64 & 11.09 & 39.75 \\
\hline $100-200+$ & 5.75 & 5.10 & 0.65 & 1.91 & 3.40 & 0.05 & 0.6 & 12.00 & 22.9 & trace & 0.68 & 6.35 & 3.00 & 10.33 & 45.10 \\
\hline \multicolumn{16}{|c|}{ Pedon 2: Nitisols } \\
\hline $0-20$ & 5.55 & 4.53 & 1.02 & 2.35 & 4.01 & 0.22 & 2.8 & 12.70 & 33.1 & trace & 1.52 & 10.6 & 2.90 & 15.02 & 45.38 \\
\hline $20-50$ & 5.46 & 4.34 & 1.12 & 2.36 & 3.40 & 0.09 & 1.9 & 21.10 & 26.9 & trace & 0.76 & 7.16 & 1.90 & 9.82 & 36.50 \\
\hline $50-130$ & 4.89 & 4.31 & 0.58 & 0.19 & 2.80 & 0.07 & 1.3 & 18.60 & 19.9 & trace & 1.29 & 0.82 & 1.31 & 3.42 & 17.19 \\
\hline $130-200+$ & 5.35 & 4.40 & 0.95 & 0.43 & 4.00 & 0.10 & 1.1 & 11.00 & 26.1 & trace & 2.05 & 5.32 & 2.60 & 9.97 & 38.20 \\
\hline \multicolumn{16}{|c|}{ Composite surface soils nearby Pedon 1 including the experimental plot } \\
\hline $0-30$ & 5.81 & 4.81 & 1.00 & 2.58 & 4.24 & 0.22 & 2.9 & 13.18 & 29.5 & trace & 2.81 & 5.90 & 1.01 & 9.72 & 32.95 \\
\hline $0-30$ & 5.89 & 4.80 & 1.09 & 2.33 & 4.22 & 0.22 & 2.7 & 12.27 & 28.7 & trace & 2.97 & 5.80 & 0.98 & 9.75 & 33.97 \\
\hline $0-30$ & 6.00 & 4.83 & 1.17 & 2.95 & 4.18 & 0.22 & 2.8 & 12.73 & 28.9 & trace & 0.53 & 5.40 & 0.87 & 6.80 & 23.53 \\
\hline Mean & 5.90 & 4.81 & 1.09 & 2.62 & 4.21 & 0.22 & 2.8 & 12.73 & 29.0 & trace & 2.10 & 5.70 & 0.95 & 8.76 & 32.55 \\
\hline \multicolumn{16}{|c|}{ Composite surface soil samples nearby Pedon 2} \\
\hline $0-30$ & 5.99 & 4.78 & 1.21 & 2.33 & 4.20 & 0.21 & 2.4 & 11.43 & 24.7 & trace & 1.60 & 6.00 & 1.10 & 8.70 & 35.22 \\
\hline $0-30$ & 5.81 & 4.75 & 1.06 & 2.34 & 4.22 & 0.21 & 2.6 & 12.38 & 22.7 & trace & 2.21 & 6.00 & 1.00 & 9.21 & 40.57 \\
\hline $0-30$ & 6.01 & 4.72 & 1.29 & 2.64 & 4.21 & 0.21 & 2.7 & 12.86 & 29.1 & trace & 2.13 & 5.42 & 1.05 & 8.60 & 29.55 \\
\hline Mean & 5.94 & 4.75 & 1.19 & 2.44 & 4.21 & 0.21 & 2.6 & 12.22 & 25.5 & trace & 1.98 & 5.81 & 1.05 & 8.84 & 35.11 \\
\hline
\end{tabular}

$* A v P=$ Available $P ; T N=$ Total $N, O C=$ Organic carbon; $C E C=$ Cation exchange capacity $;$ TEB = Total exchangeable bases; $P B S=$ Percent base saturation 
group level. Moreover, the percentage base saturation throughout the depths of both soil profiles was below $50 \%$. This property suggests that the soils further qualify to be classified as Dystric Nitisols at the second level of classification of the FAO system (FAO, 1998).

\subsection{Native and Residual Soil Phosphorus}

The Olsen extractable $\mathrm{P}$ of the soils in the study area was very low $(<5 \mathrm{ppm})$ as per the ratings of Olsen $e t$ al. (1954). Similarly, the Bray II extractable P was low $(<3 \mathrm{ppm})$ as described by Olsen and Dean (1965). The highest concentrations of Olsen extractable phosphorus (3.21 ppm) and Bray II extractable phosphorus (4.40 ppm) were obtained in the surface horizon of pedon 1 (Table 3). Available $P$ values are still lower in the composite surface soil samples of the cultivated fields near the two pedons. Generally, both the Olsen and Bray II extractable $\mathrm{P}$ values of the soils are far below the critical soil test $\mathrm{P}$ levels for most crop plants as reported by Tekalign and Haque (1991) for Ethiopian soils. This low soil test levels of available $\mathrm{P}$ may be due to the inherently low P levels of the soil or due its high $\mathrm{P}$ fixation capacity caused by the strongly acidic $(\mathrm{pH}$ $\mathrm{KCl})$ and moderately acidic $\left(\mathrm{pH} \mathrm{H}_{2} \mathrm{O}\right)$ soil reactions.

The results of the Olsen and Bray II extractable soil $\mathrm{P}$ determined on soil samples collected from every treatment combination at harvest are presented in Table 4. The main effects of increasing levels of applied $\mathrm{N}$ fertilizer on soil $\mathrm{P}$ extracted by both methods were not consistent although the Bray II $\mathrm{P}$ tended to increase while the Olsen $\mathrm{P}$ showed a decreasing trend with increasing applied $\mathrm{N}$ rates. Considering the main effect of applied $\mathrm{N}$, the highest values of Bray II $(5.16 \mathrm{~kg}$ ha $\left.{ }^{1}\right)$ and Olsen $\left(4.32 \mathrm{~kg} \mathrm{ha}^{-1}\right)$ extractable soil $\mathrm{P}$ were obtained with the application of $\mathrm{N}$ at 46 and $0 \mathrm{~kg} \mathrm{ha}^{-1}$, respectively. Nevertheless, without applied $\mathrm{P}$, increasing the levels of $\mathrm{N}$ fertilizer from 0 to $92 \mathrm{~kg} \mathrm{ha}^{-1}$ increased consistently the Bray II P from $2.80-4.80 \mathrm{~kg}$ $\mathrm{ha}^{-1}$ and the Olsen P from 1.65-2.53 kg ha ${ }^{-1}$ (Table 4).

On the contrary, application of $\mathrm{P}$ fertilizer increased both the Olsen and Bray II extractable available soil $\mathrm{P}$ consistently (Table 4). Averaged across all levels of applied $\mathrm{N}$ fertilizer rates, the Bray II extractable soil $\mathrm{P}$ increased from 3.84 to $5.64 \mathrm{~kg} \mathrm{ha}^{-1}$ and Olsen $\mathrm{P}$ from 2.15 to $4.26 \mathrm{~kg} \mathrm{ha}^{-1}$ when the rate of applied $\mathrm{P}$ fertilizer increased from 0 to $40 \mathrm{~kg} \mathrm{P} \mathrm{ha}{ }^{-1}$. In the absence of applied $\mathrm{N}$ fertilizer, the Bray II extractable soil $\mathrm{P}$ increased consistently from $2.80-6.20 \mathrm{~kg} \mathrm{ha}^{-1}$ with the increment of $\mathrm{P}$ fertilizer rate from 0 to $30 \mathrm{~kg} \mathrm{P} \mathrm{ha}^{-1}$ whereas the Olsen $P$ increased from $1.65-8.02 \mathrm{~kg} \mathrm{ha}^{-1}$ when the rate of applied $\mathrm{P}$ fertilizer increased from 0 to $40 \mathrm{~kg} \mathrm{P} \mathrm{ha}^{-1}$ (Table 4). The increment of both Bray II and Olsen extractable soil $\mathrm{P}$ with increasing applied rates of $\mathrm{P}$ fertilizer indicates that the crop recovery of applied P was low and a considerable amount of the applied phosphorus fertilizer has been left in the soil as a residual $P$.

Table 4. Effects of increasing levels of $\mathrm{N}$ and $\mathrm{P}$ application on Olsen and Bray II available P contents of the soil

\begin{tabular}{|c|c|c|c|c|c|c|}
\hline \multirow{2}{*}{$\begin{array}{l}\text { Applied N } \\
\left(\mathrm{kg} \mathrm{ha}^{-1}\right)\end{array}$} & \multicolumn{5}{|c|}{ Applied P $\left(\mathrm{kg} \mathrm{ha}^{-1}\right)$} & \multirow[t]{2}{*}{ Mean } \\
\hline & 0 & 10 & 20 & 30 & 40 & \\
\hline \multicolumn{7}{|c|}{ Bray II available $\mathrm{P}\left(\mathrm{mg} \mathrm{l}^{-1}\right)$} \\
\hline 0 & 2.80 & 3.20 & 5.00 & 6.20 & 5.00 & 4.44 \\
\hline 23 & 3.60 & 4.40 & 4.60 & 5.00 & 4.60 & 4.44 \\
\hline 46 & 4.00 & 4.80 & 4.00 & 5.40 & 7.60 & 5.16 \\
\hline 69 & 4.00 & 4.20 & 5.60 & 5.40 & 6.00 & 5.04 \\
\hline 92 & 4.80 & 3.80 & 4.60 & 5.00 & 5.00 & 4.64 \\
\hline Mean & 3.84 & 4.08 & 4.76 & 5.40 & 5.64 & 4.74 \\
\hline Applied N & \multicolumn{5}{|c|}{ Applied P (kg ha $\left.{ }^{-1}\right)$} & Mean \\
\hline$\left(\mathrm{kg} \mathrm{ha}^{-1}\right)$ & 0 & 10 & 20 & 30 & 40 & \\
\hline \multicolumn{7}{|c|}{ Olsen available $\mathrm{P}\left(\mathrm{mg} \mathrm{l}^{-1}\right)$} \\
\hline 0 & 1.65 & 2.01 & 4.21 & 5.74 & 8.02 & 4.32 \\
\hline 23 & 1.92 & 2.66 & 2.39 & 3.44 & 2.65 & 2.61 \\
\hline 46 & 2.16 & 3.41 & 2.52 & 3.74 & 3.83 & 3.13 \\
\hline 69 & 2.50 & 2.15 & 3.45 & 2.95 & 3.78 & 2.97 \\
\hline 92 & 2.53 & 4.63 & 2.72 & 3.26 & 3.01 & 3.23 \\
\hline Mean & 2.15 & 2.97 & 3.06 & 3.82 & 4.26 & 3.25 \\
\hline
\end{tabular}




\section{Conclusion}

Examination of the pedons revealed that the soils exhibited high levels of clay accumulation with increasing depth and silty clay to clay in texture. The reddish brown and red soil characteristics with nitic properties on the exposed surfaces having shiny, lustrous ped faces and their chemical properties lead to the classification of this soil into Nitisol. In both pedons, the lowest bulk density values were recorded at the surface horizons. Higher values of $\mathrm{pH}\left(\mathrm{H}_{2} \mathrm{O}\right)$, available $\mathrm{P}$ (Bray II), total $\mathrm{N}$, organic matter, CEC, total exchangeable bases and percentage base saturation were observed in the surface soil horizons and the composite surface soil samples than in the subsurface horizons of the pedons.

The Olsen and Bray II soil test $\mathrm{P}$ values revealed that the soils of the study area are very low and low, respectively, and are far below the critical soil test $\mathrm{P}$ values for most crop plants as per the results of similar studies under Ethiopian conditions. Similarly, the organic carbon and total $\mathrm{N}$ status of the soils are moderate whereas exchangeable $\mathrm{Ca}$ is medium, $\mathrm{Mg}$ is high and $\mathrm{K}$ is high to very high. Application of $\mathrm{P}$ fertilizer increased both the Olsen and Bray II extractable soil available $\mathrm{P}$ consistently. This further indicates that crop recovery of applied $\mathrm{P}$ fertilizer in one season is low and therefore much of the applied $\mathrm{P}$ remains in the soil as available form of $\mathrm{P}$ for subsequent use by crop plants. Apparently, the results of this study provide basic information and baseline data for further research and development efforts in soil fertility management for sustainable utilization of the soil resources in the area. However, further detailed study and analysis should be carried out on the soils around Ayehu in order to supplement the results of this specific location and one year study so that sound conclusions can be drawn and recommendations made.

\section{Acknowledgement}

The authors acknowledge the Amhara Region Agricultural Research Institute (ARARI) in general and the Adet Agricultural Research Center in particular for supporting the study financially through their Agricultural Research and Training Project (ARTP) fund.

\section{References}

Asfaw, B., Heluf, G., Yohannes, U. and Eylachew, Z. 1997. Effect of crop residues on grain yield of sorghum (Sorghum bicolor) (L.) to application of $\mathrm{N}$ and $\mathrm{P}$ Fertilizers. Nutrient Cycling in Agroecosystems 48: 191-196.

Blake, G.R. 1965. Bulk density. In: C.A. Black (ed.). Methods of Soil Analysis. Agron. Part I, No. 9, Am. Soc. Agron. Madison, Wisconsin, USA. pp. 374-399.

Bouyoucos, G.J. 1962. Hydrometer method improved for making particle size analyses of soils. Agronomy Journal 54: 464-465.

Brady, N.C. and Weil, R.R. 2002. The Nature and Properties of Soils, $13^{\text {th }}$ edition. Person Education Ltd., USA.
Bray, R.H. and Kurtz, L.T. 1945. Determination of total, organic and available forms of phosphorus in soils. Soil Science Society of America Proceedings 59: 39-45.

Chapman, H.D. 1965. Cation exchange capacity by ammonium saturation. In: C.A. Black (ed.). Methods of Soil Analysis. Agronomy Part II, No 9, Am. Soc. Agron. Madison, Wisconsin, USA. pp. 891-901.

FAO (Food and Agriculture Organization). 1990. Guidelines for soil description ( $3^{\text {rd }}$ edition), Rome, Italy.

FAO (Food and Agriculture Organization). 1998. World reference base for soil resources. FAO, ISRIC and ISSS, Rome, Italy.

FAO (Food and Agriculture Organization). 2001. Soil fertility management in support of food security in Sub-Saharan Africa (SSA), Rome, Italy.

Jackson, M.L. 1970. Soil Chemical Analysis. Prentice Hall, Inc., Engle Wood Cliffs, New Jersey.

Kang, B.T. 1993. Changes in soil chemical properties and crop performance with continuous cropping on Entisols in the humid tropics. In: K. Mulongoy and R. Merck (eds.). Proceedings of International Symposium. 4-6 November 1991, Laboratory of Soil Fertility and Biology, Katholieke Unversiteit, and International Institute of Tropical Agriculture (IITA). Leuven, Belgium. pp. 297-306.

Martel, Y.A. and Mackenzie, A.F. 1980. Long-term effects of cultivation and land use on soil quality in Quebec. Canadian Journal of Soil Science 60: 411-420.

Mishra, B.B., Heluf, G. and Kibebew, K. 2004. Soils of Ethiopia: Perceptions, appraisal and constraints in relation to food security. Journal of Food, Agriculture and Environment 2: 269-279.

Mohammed, A., Le Roux, P.A.L., Barker, C.H. and Heluf, G. 2005. Soils of Jelo Micro-Catchment in the Chercher Highlands of Eastern Ethiopia: I. Morphological and physicochemical properties. Ethiopian Journal of Natural Resources 7: 5581.

Olsen, S.R, Cole, C.V., Watanabe, F.S. and Dean, L.A. 1954. Estimation of available phosphorus in soils by extraction with sodium bicarbonate. USDA Circular 939.

Olsen, S.R. and Dean, L.A. 1965. Phosphorus. In: C.A. Black (ed.). Methods of Soil Analysis. II. Chemical and Microbiological Properties. No. 9, Agronomy Series. Am. Soc. Agron. Madison, Wisconsin, USA. pp. 1035-1049.

Sahlemedhin, S. 1999. Draft guideline for regional soil testing laboratories. NFIA, Addis Ababa, Ethiopia.

Saikh, H., Varadachari, C. and Ghosh, K. 1998a. Changes in carbon, nitrogen and phosphorus levels due to deforestation and cultivation. A case study in Simplipal National Park, India. Plant and Soil 198: 137-145.

Saikh, H., Varadachari, C. and Ghosh, K. 1998b. Effects of deforestation and cultivation on soil $\mathrm{CEC}$ and contents of exchangeable bases. A case 
study in Simplipal National Park, India. Plant Soil 204: 67-75.

Singh, H., Sharma, K.N. and Arora, B.S. 1995. Influence of continuous fertilization to maze system on the changes in soil fertility. Fertilizer Research 40: 7-19.

Smaling, E.M.A., Nandwa, S.M. and Janssen, B.H. 1997. Soil fertility in Africa is at stake. In: R.J. Buresh, P.A. Sanchez and F. Calhoom (eds.) Replenishing Soil Fertility in Africa. Soil Science Society of America Special Publ. 51. Madison, Wisconsin, USA. pp. 47-61.

Tekalign, M. and Haque, I. 1991. Phosphorus status of some Ethiopian soils. III. Evaluation of soil test methods for available phosphorus. Tropical Agriculture (Trinidad) 65: 51-56.

Tekalign, M., Haque, I. and Aduayi, E.A. 1991. Soil, plant, water, fertilizer, animal manure and compost analysis manual. Working Document Number B13. Soil Science and Plant Nutrition Section, International Livestock Center for Africa, Addis Ababa, Ethiopia.

Wakene, N. and Heluf, G. 2003. Forms of phosphorus and status of available micronutrients under different land use systems of Alfisols in Bako area of Ethiopia. Ethiopian Journal of Natural Resources 5: 17-37.

Walkley, A. and Black, I.A. 1934. An examination of the Degtjareff method for determining soil organic matter and a proposed modification of the chromic acid titration method. Soil Science 37: 29-38. 